\title{
Ektrak Daging Buah Mahkota Dewa Meregenerasi Sel Pulau Langerhans Pada Tikus Putih Diabetes
}

\author{
FITRANTO ARJADI ${ }^{1}$ DAN MUSTOFA ${ }^{2}$ \\ ${ }^{1}$ Bagian Anatomi, Fakultas Kedokteran, Universitas Jenderal Soedirman \\ ${ }^{2}$ Bagian Fisiologi, Fakultas Kedokteran, Universitas Jenderal Soedirman \\ Jl. dr. Gumbreg No. 1 Berkoh, Purwokerto, Jawa Tengah 53112 \\ email: f.arjadi@yahoo.com
}

\begin{abstract}
In Indonesia, the increasing prevalence of diabetes mellitus is accompanied by the increasing financial burden to the patients. It is necessary to find alternative herbal treatment for diabetes, which is effective, cheap, and easy to find: the mahkota dewa. This research aims to find out the histological regeneration of Langerhans islet cells after given by flesh extract of mahkota dewa.

This experimental research used complete randomized design (CRD). There were 5 treatments given to the twenty five mice; the negative control group (the normal one), the positive control (male white mice (Rattus norvegicus which were made diabetic by administering injection of 70 $\mathrm{mg} / \mathrm{kg}$ of body mass of diabetogenic alloxan), the group of diabetic male white mice given 3, 6 and 9 grams/day/200 bodyweights), then were measured glucose in blood at $0,1^{\text {st }}$ and $4^{\text {th }}$ week and counted Langerhans islet cells every 5 overviews.

Statistically results showed that flesh extracts of mahkota dewa can decreased glucose in diabetic mice $(\mathrm{r}=0,75)$ with contribute $56,89 \%$ in decreasing, regenerated Langerhans islet cells of pankreas $\left\{\mathrm{F}^{\text {count }}(17,558)>\mathrm{F}^{\mathrm{tab}}(2,870)\right\}$ with the highest increasing is 3,84 amount and started with 3 grams/day/200 bodyweights doses, and the best effectiveness in regenerating was 11,81\% consentration or 0,1181 grams/day (6.56 grams/day in human).
\end{abstract}

Keywords: flesh extracts, Langerhans islet cells of pankreas, mahkota dewa, regenerate

\section{INTISARI}

Di Indonesia, prevalensi penyakit diabetes melitus semakin meningkat yang diikuti dengan biaya perawatan penderita yang ikut meningkat sehingga perlu dipikirkan alternatif pengobatan dari tanaman obat tradisional Indonesia yang manjur, murah, dan mudah yaitu mahkota dewa. Penelitian bertujuan mengetahui adanya regenerasi sel pulau Langerhans pankreas tikus (Rattus norvegicus) diabetes yang telah diberi ekstrak daging buah mahkotadewa

Jenis penelitian adalah eksperimental menggunakan Rancangan Acak Lengkap (RAL) pada 25 tikus putih dengan 5 perlakuan yaitu, kontrol negatif, kontrol (diberi injeksi diabetogen aloksan dengan dosis $70 \mathrm{mg} / \mathrm{kg} \mathrm{BB}$ ) dan 3 kelompok perlakuan (diberi ekstrak buah mahkota dewa dengan konsentrasi 3, 6 dan 9 gram /hari/200gBB), kemudian diukur glukosa darah pada minggu ke- 0, 1 dan 4 serta dihitung sel pulau Langerhans tiap 5 lapangan pandang.

Hasil uji statistik menunjukkan bahwa ekstrak buah mahkotadewa dapat menurunkan kadar glukosa darah pada tikus diabetes $(\mathrm{r}=0,75)$ dengan kontribusi 56,89\% menurunkan glukosa darah, meregenerasi sel pulau Langerhans pankreas tikus diabetes $\left\{\mathrm{F}^{\text {hit }}(17,558)>\mathrm{F}^{\text {tab }}(2,870)\right\}$ dengan peningkatan jumlah sel pulau Langerhans pankreas tertinggi adalah 3,84 buah dan pada konsentrasi $3 \mathrm{gr} / 200 \mathrm{gr} /$ hari mulai mampu meregenerasi sel pulau Langerhans pankreas tikus diabetes dengan dosis ekstrak mahkota dewa yang paling efektif adalah kadar $11,81 \%$ atau 0,1181 gram/gram(6.56 gram/hari pada manusia).

Kata kunci: ekstrak daging buah, mahkota dewa, regenerasi, sel pulau Langerhans pankreas 


\section{PENDAHULUAN}

Jumlah pasien Diabetes Melitus (DM) di dunia maupun di Indonesia semakin lama semakin meningkat. Data Badan Kesehatan Dunia (WHO) tahun 2003, jumlah penderita DM mencapai 194 juta jiwa dan diperkirakan meningkat menjadi 333 juta jiwa di tahun 2025 mendatang, dan setengah dari angka tersebut terjadi di negara berkembang. Indonesia menduduki tempat ke 4 terbesar dengan pertumbuhan sebesar $152 \%$ atau dari 8.426 .000 orang pada tahun 2.000 menjadi 21.257.000 orang di tahun 2030 (Daud dan Afrida, 2014). Biaya perawatan penderita DM, baik di negara maju maupun di negara berkembang sangat tinggi. Di Indonesia, biaya perawatan komplikasi DM, misalnya gangren Rp. 1,3-1,6 juta per penderita tiap bulan atau Rp. 43,5 juta per tahun dan untuk hemodialisa bila penderita gagal ginjal mencapai Rp.150.000-200.000 juta per hemodialisa (Darmono, 2009).

Selama ini pengobatan DM dilakukan dengan pemberian obat oral anti diabetik (OAD) atau suntikan insulin yang jika dilakukan secara terus menerus dapat menghabiskan biaya yang besar dan menjadi beban berat bagi penderitanya. Faktor sosial ekonomi ini yang sering menyebabkan kegagalan penderita dalam mengontrol kadar gula darahnya sehingga perlu dipikirkan alternatif pengobatan yang manjur, murah, dan mudah didapat.

Dengan prinsip kembali ke alam, penggunaan ramuan tradisional kembali dilirik untuk dieksplorasi dan diteliti khasiatnya dalam membantu penyembuhan berbagai penyakit. Salah satu tanaman obat tradisional Indonesia yang sudah terkenal dan khasiatnya dipercaya dapat menyembuhkan diabetes adalah mahkota dewa. Daun, bunga maupun daging buah mahkota dewa dapat digunakan sebagai obat (Pribadi, 2012). Pada daging buah mahkota dewa mengandung senyawa flavonoid, saponin dan alkaloid (Djazuli, 2011). Senyawa kimia aktif yang diduga mempunyai efek hipoglikemik mirip insulin adalah flavonoid yang dapat meningkatkan pengeluaran insulin merubah metabolisme $\mathrm{Ca}^{2+}$ (Ramachandran dan Rajasekaran, 2014) dan meregenerasi pulau Langerhans pankreas terutama sel $\beta$ (Cicero et al., 2013).

Hasil penelitian sebelumnya menunjukkan peningkatan jumlah rerata sel Pulau Langerhans dimulai pada pemberian rebusan buah mahkota dewa dengan kadar 9\%, terdapat hubungan yang kuat antara rebusan buah mahkota dewa dengan penurunan kadar glukosa darah $(\mathrm{r}=0,66)$ dan memberi kontribusi $43,82 \%$ dalam penurunan glukosa darah (Arjadi dan Susatyo, 2017).

Tujuan penelitian adalah menguji secara histologis regenerasi (perbaikan kembali) sel $\beta$ pulau Langerhans pankreas yang rusak pada tikus diabetes dengan pemberian ekstrak daging buah mahkota dewa. Hasil penelitian awal ini diharapkan dapat menjadi dasar penggunaan ekstrak daging buah mahkota dewa sebagai salah satu alternatif pengobatan DM.

\section{METODE}

Jenis penelitian adalah eksperimental murni dengan menggunakan Rancangan Acak Lengkap (RAL). Hewan coba sebanyak 25 ekor tikus putih (Rattus norvegicus) jantan galur Sprague Dawley umur 75-90 hari dan berat badan 100-150 gram, dipelihara dalam lingkungan dan makanan yang sama. Pemberian ekstrak buah mahkota dewa diberikan pada pagi hari sedangkan pakan tikus BR II diberikan siang dan sore dengan jumlah maksimal 20 gram/hari.

Buah mahkota dewa diambil dari pasar Wage, Purwokerto yang matang dan berwarna merah menyala. Cara pembuatan ekstrak buah mahkota dewa dengan dimaserasi, yaitu direndam dalam air 3x24 jam sampai diperoleh sarinya, diuapkan sampai kental, dikeringkan dengan diangin-anginkan sampai diperoleh ekstrak kering (Widyastuti dkk., 2008). Ekstrak buah mahkota dewa dibuat konsentrasi 3 , 6, dan 9 gram/hari/200gBB ditambahkan air secukupnya dan diberikan melalui sonde ke lambung tikus (Sulistyoningrum dkk.,2010).

Perlakuan terhadap hewan coba meliputi kontrol negatif, kontrol positif (kelompok yang diinjeksi diabetogen aloksan dosis $70 \mathrm{mg} / \mathrm{kg}$ BB saja), kelompok perlakuan III (ekstrak buah mahkota dewa dengan konsentrasi 3 gram 
/hari/200gBB), kelompok IV (6 gram/hari/200gBB) dan kelompok perlakuan V (9 gram /hari/200gBB). Kelompok II, III, IV, dan $\mathrm{V}$ sebelumnya diinjeksi diabetogen aloksan.

Variabel penelitian adalah kadar gula darah sebelum dan sesudah penelitian, jumlah dan diameter sel pulau Langerhans pada semua perlakuan. Jumlah dan diameter sel $\beta$ pulau Langerhans diukur tiap 5 buah lapangan pandang tiap preparat. Pankreas tiap hewan coba pada semua perlakuan dibuat masingmasing 5 buah preparat.

Data hasil percobaan ditunjukkan dengan mean $\pm \mathrm{SD}$, dianalisis dengan uji Analysis of
Variance (ANOVA) one way, taraf kepercayaan $95 \%(\alpha=0,05)$ dan melihat besar pengaruh perlakuan diuji dengan menggunakan uji beda nyata terkecil (BNT) pada $\alpha=0,05$.

\section{HASIL}

Kadar Glukosa. Data penelitian menunjukkan peningkatan kadar glukosa darah yang cukup drastis pada minggu ke-1 pada kontrol positif dan perlakuan (Grafik 1) yang membuktikan adanya kerusakan sel $\beta$ pulau Langerhans pankreas akibat pemberian aloksan dengan dosis sebesar $70 \mathrm{mg} / \mathrm{kg} \mathrm{BB}$ intravena.

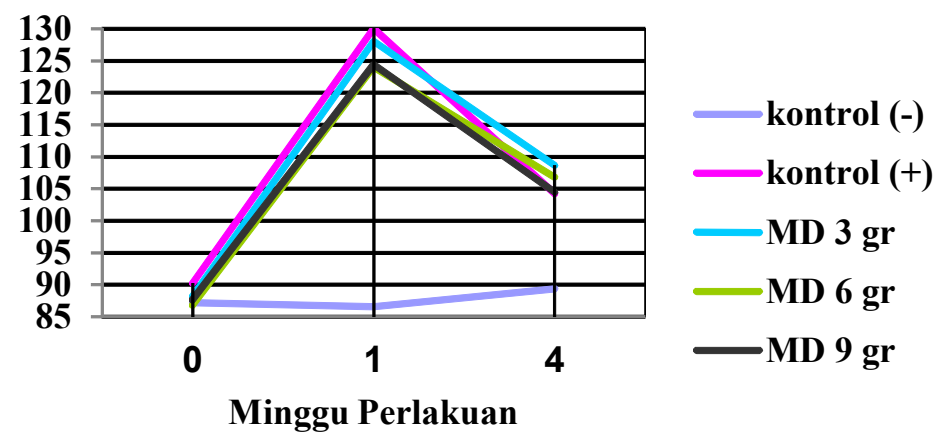

Grafik 1. Kadar glukosa pada minggu 0, ke-1 dan ke-4 perlakuan

Aloksan merupakan bahan kimia yang digunakan untuk menginduksi diabetes pada binatang percobaan dengan efek antagonis terhadap glutathion yang bereaksi dengan gugus SH-nya. Aloksan berikatan dengan Glut2 yang memfasilitasi masuknya aloksan ke dalam sitoplasma sel $\beta$ pankreas, meningkatkan depolarisasi pada mitokondria sebagai akibat pemasukan ion $\mathrm{Ca}^{2+}$ yang diikuti dengan penggunaan energi berlebih sehingga terjadi kekurangan energi dalam sel. Dua mekanisme tersebut merusak jumlah dan massa sel pankreas sehingga terjadi penurunan pelepasan insulin (Widowati, 2008).

Hipotesis mekanisme aksi lain yang diajukan adalah pembentukan khelat terhadap $\mathrm{Zn}$, interferensi dengan enzim-enzim sel, deaminasi dan dekarboksilasi asam amino. Penelitian terhadap mekanisme kerja aloksan secara invitro menunjukkan bahwa aloksan menginduksi pengeluaran ion kalsium dari mitokondria yang mengakibatkan proses oksidasi sel terganggu yang merupakan awal dari matinya sel (Sulistyoningrum dkk., 2012).

Aksi sitotoksik aloksan sebagai agen diabetogenik diperantai oleh radikal bebas. Aloksan dan produk reduksinya, asam diakurat, mempertahankan siklus redoks dengan pembentukan radikal superoksida yang kemudian mengalami dismutasi menjadi hidrogen peroksida. Radikal hidroksil yang tinggi terbentuk oleh reaksi Fenton. Aksi radikal bebas dengan peningkatan kadar kalsium sitosol yang hebat dan simultan menyebabkan kerusakan sel $\beta$ dengan cepat.

\section{Kadar Glukosa dan Ekstrak Daging}

Buah Mahkota Dewa. Pemberian ekstrak daging buah mahkota dewa pada minggu ke-4 menunjukkan penurunan kadar glukosa yang nyata (Tabel 1), sesuai dengan Anggiasih et al., (2009) yang menunjukkan penurunan kadar gula darah tikus putih (Rattus norvegicus) yang diinduksi aloksan secara signifikan pada ketiga kelompok dosis dan 
efek penurunan terbesar justru terdapat pada kelompok dosis yang terkecil.

Tabel 1. Kadar Glukosa Darah Tikus Putih pada Minggu ke-0, 1, dan 4

\begin{tabular}{|c|c|c|c|c|c|c|c|c|c|}
\hline \multirow{2}{*}{\multicolumn{2}{|c|}{$\begin{array}{l}\text { Kelompok } \\
\text { Perlakuan }\end{array}$}} & \multirow[t]{2}{*}{$\begin{array}{l}\text { Minggu } \\
\text { ke- }\end{array}$} & \multicolumn{7}{|c|}{ Kadar Glukosa Darah (mg\%) } \\
\hline & & & 1 & 2 & 3 & 4 & 5 & $\mathrm{X}$ & SD \\
\hline \multirow[t]{3}{*}{ I. } & Kontrol (-) & 0 & 85 & 88 & 95 & 88 & 80 & 87,2 & $\pm 8,22$ \\
\hline & Normal & 1 & 88 & 88 & 98 & 80 & 79 & 86,6 & $\pm 7,86$ \\
\hline & & 4 & 92 & 96 & 90 & 85 & 84 & 89,4 & $\pm 6,04$ \\
\hline & Kontrol (+) & 0 & 95 & 78 & 88 & 96 & 94 & 90,2 & $\pm 12,94$ \\
\hline & Aloksan Ekstrak & 1 & 126 & 134 & 120 & 125 & 130 & 130 & $\pm 6,06$ \\
\hline & MD 3 gr & 4 & 129 & 126 & 128 & 129 & 138 & 104,2 & $\pm 7,73$ \\
\hline & Aloksan Ekstrak & 0 & 96 & 80 & 94 & 92 & 79 & 88,2 & $\pm 6,15$ \\
\hline & MD $6 \mathrm{gr}$ & 1 & 128 & 126 & 122 & 124 & 140 & 128 & $\pm 11,48$ \\
\hline & & 4 & 106 & 105 & 108 & 108 & 116 & 108,6 & $\pm 8,02$ \\
\hline \multirow[t]{3}{*}{ IV } & Aloksan Ekstrak & 0 & 90 & 89 & 79 & 86 & 90 & 86,8 & $\pm 6,38$ \\
\hline & MD $9 \mathrm{gr}$ & 1 & 124 & 120 & 138 & 115 & 123 & 124 & $\pm 8,57$ \\
\hline & & 4 & 98 & 105 & 109 & 108 & 114 & 106,8 & $\pm 6,76$ \\
\hline & Aloksan Ekstrak & 0 & 79 & 93 & 88 & 92 & 86 & 87,6 & $\pm 9,57$ \\
\hline & MD 12 gr & 1 & 120 & 128 & 122 & 128 & 124 & 124,4 & $\pm 7,92$ \\
\hline & & 4 & 112 & 105 & 97 & 102 & 106 & 104,4 & $\pm 5,63$ \\
\hline
\end{tabular}

Penelitian lain yaitu dengan menggunakan infusa daging buah mahkota dewa kadar glukosa darahnya pada menit ke 30, 60, 90, dan 120 darah yang signifikan pada keempat kelompok diatas, dan efek penurunan terbesar terdapat pada kelompok IV dengan konsentrasi 20\% (Primasari, 2017).

Pemberian ekstrak mahkota dewa menunjukkan peningkatan sel pulau Langerhans yang signifikan secara statistik menggunakan ANOVA yaitu $\mathrm{F}^{\text {hit }}(17,558)>\mathrm{F}^{\mathrm{tab}}$ $(2,870)$ dengan $\alpha=0,05$. Uji ortogonal untuk melihat pengaruh perlakuan berbagai dosis dengan juga menunjukkan $\mathrm{F}^{\text {hit }}(38,322)>\mathrm{F}^{\mathrm{tab}}$ (4,350). Hubungan liner yang dinyatakan dengan regresi dengan $\mathrm{Y}=2,132+0,144889 \mathrm{X}$ dengan koeffisien determinasi $\left(\mathrm{r}^{2}\right)=$ $56,899903 \%$ dan koefisien korelasi (r)= 0,754314 menunjukkan ekstrak daging buah mahkota dewa memberikan kontribusi 56,89\% dalam penurunan glukosa darah dan terdapat hubungan yang kuat antara mahkota dewa dengan penurunan kadar glukosa darah $(\mathrm{r}=$ 0,75). Uji regresi linier menunjukkan sifat positif yang berarti semakin besar dosis rebusan buah mahkota dewa menurunkan kadar glukosa darah. Hubungan kuadrater yang dinyatakan dengan regresi dengan $\mathrm{Y}=1,842+$ $0,338222 \mathrm{X}-0,014321 \mathrm{X}^{2}$ dengan koefisien determinasi sebesar $65,940427 \%$ dengan titik belok $\mathrm{x}=11,81$ dan $\mathrm{y}=3,84$ menunjukkan tingkat dosis ekstrak mahkota dewa yang paling efektif adalah pada kadar $11,81 \%$ atau 0,1181 gram dengan peningkatan jumlah sel pulau Langerhans pankreas tertinggi adalah 3,84 .

Penurunan kadar glukosa darah akibat pemberian ekstrak buah mahkota dewa dapat dijelaskan melalui dua mekanisme utama, yaitu secara intra pankreatik dan ekstra pankreatik. Mekanisme intra pankreatik bekerja dengan cara memperbaiki (regenerasi) sel $\beta$ pankreas yang rusak dan melindungi sel $\beta$ dari kerusakan serta merangsang pelepasan insulin dengan senyawa aktif alkaloid dan flavonoid (Abdel-Aziz et al., 2013). Peningkatan sekresi insulin diakibatkan oleh adanya efek perangsangan saraf simpatis (simpatomimetik) dari alkaloid yang berefek pada meningkatnya sekresi insulin. Flavonoid mempunyai sifat sebagai antioksidan sehingga dapat melindungi kerusakan sel-sel pankreas dari radikal bebas.

Hasil pengujian aktivitas antioksidan ekstrak tanaman mahkota dewa dengan menggunakan metode larutan DPPH (2,2diphenyl-1-picrylhydrazy) secara spektrofotometri Uv.Vis menunjukkan ekstrak semi polar dan polar daging buah dan kulit biji 
tanaman mahkota dewa memiliki aktifitas antioksidan yang cukup potensial dengan nilai LC50 antara 94,89 - 136,79 ug/ml. Hasil pengujian tersebut menunjukkan adanya potensi antioksidan dari ekstrak daging buah mahkota dewa yang menambah bioaktifitas sehingga dapat dijadikan obat alternatif berdasar penelitian ilmiah.

Mekanisme kedua, yaitu ekstra pankreatik dapat berlangsung melalui berbagai mekanisme. Alkaloid menurunkan glukosa darah dengan cara menghambat absorbsi glukosa di usus, meningkatkan transportasi glukosa di dalam darah merangsang sintesis glikogen dan menghambat sintesis glukosa dengan menghambat enzim glukosa 6fosfatase, fruktosa 1,6-bifosfatase serta meningkatkan oksidasi glukosa melalui glukosa 6-fosfat dehidrogenase. Glukosa 6fosfatase dan fruktosa 1,6-bifosfatase merupakan enzim yang berperan dalam glukoneogenesis.

Penghambatan pada kedua enzim ini menurunkan pembentukan glukosa dari substrat lain selain karbohidrat. Saponin menurunkan absorbsi glukosa di usus, menghambat transporter glukosa Glut-1, meningkatkan pemanfaatan glukosa di jaringan perifer, dan penyimpanan glikogen serta peningkatan sensitifitas reseptor insulin di jaringan. Beberapa mekanisme yang telah disebutkan masih membutuhkan penelitian lebih lanjut untuk mengetahui mekanisme lain dari proses hipoglikemi yang ditimbulkan.

Jumlah dan Sel Pulau Langerhans. Pada penghitungan jumlah rerata sel pulau Langerhans terdapat peningkatan mulai pada pemberian ekstrak buah mahkota dewa $3 \mathrm{gr} / \mathrm{hari} / 200 \mathrm{gBB}$ yang mampu menaikkan rerata jumlah sel Langerhams (Gambar 2), tetapi belum mencapai dosis terapi, karena menurut statistik dosis yang diberikan adalah $0,1181 \mathrm{gr} / \mathrm{hari} / \mathrm{gBB}$ sehingga jika berat tikus rata-rata $100 \mathrm{gr}$ maka dosis yang diperlukan adalah 11,81gr/hari. Pada kontrol positif, sel pulau Langerhans rusak disebabkan karena radikal oksigen bebas sejak sistem pertahanan antioksidan rusak karena diabetes atau aloksan (Srinivasan et al., 2013).

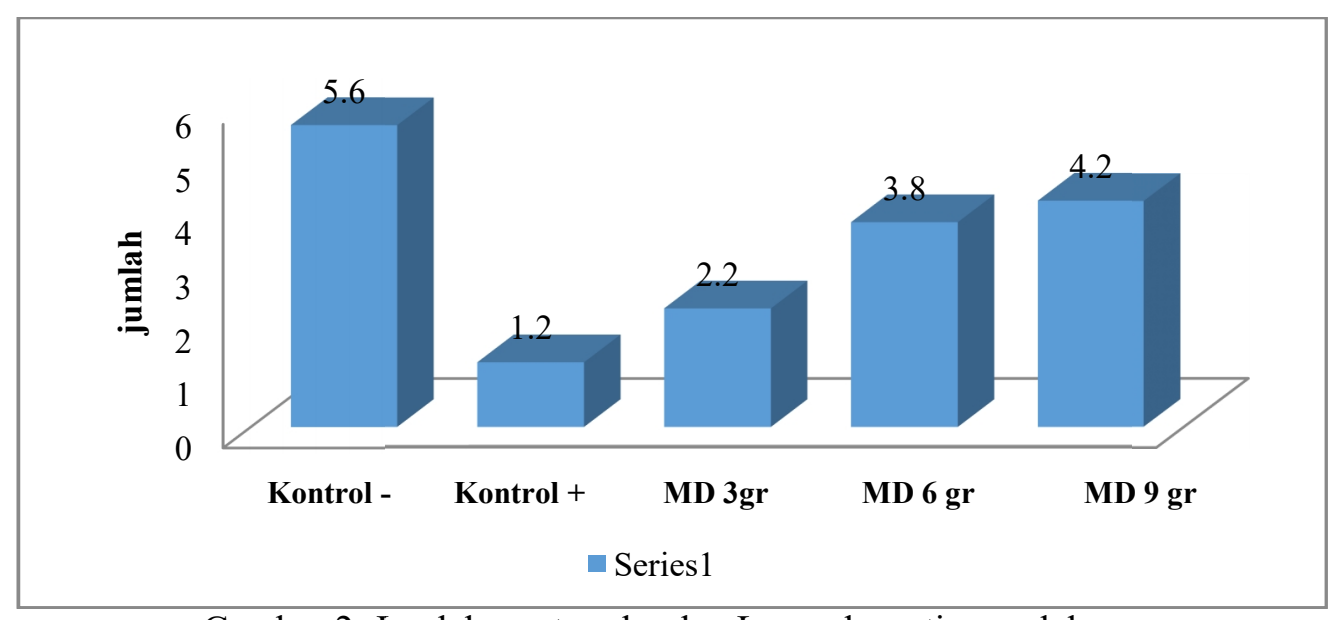

Gambar 2. Jumlah rerata sel pulau Langerhans tiap perlakuan

\section{PEMBAHASAN}

Mahkota dewa yang mempunyai kandungan senyawa aktif flavonoid yang bersifat sebagai antioksidan sehingga dapat melindungi kerusakan sel-sel pankreas dari radikal bebas. Dalam daging buah mahkota dewa terkandung senyawa alkaloid, saponin, dan flavonoid, sedang dalam daunnya terkandung alkaloid, saponin, serta polifenol. Menurut Zhang et al. (2009) komponen kimia yang ada di buah mahkota dewa adalah glikosida fenolik yang dinamakan mahkoside A, dengan enam senyawa lain meliputi mangiferin, kaempferol-3-O- $\beta$-d-glukosida, asam dodekanoat, asam palmitat, etil stearat dan sukrosa (Gotama dkk., 2014).

Salah satu zat flavonoid dengan efek hipoglikemi adalah quercetin yang mampu meningkatkan pengeluaran insulin dari sel pulau Langerhans melalui perubahan 
metabolisme $\mathrm{Ca}^{+2}$ (Hii dan Howell, 2015). Efek quercetin lain adalah menginduksi hepatik glukokinase dan hasilnya menciptakan efek hipoglikemi, mampu merangsang pengeluaran insulin dan/atau mempunyai senyawa mirip insulin yang dapat diekstraksi, meregenerasi sel $\beta$ sehingga meningkatkan jumlah sel $\beta$ sebagai penyusun utama $(60 \%)$ pulau Langerhans akhirnya meningkatkan diameter sel. Secara umum daya regenerasi sel dipengaruhi oleh nutrisi, aktivitas olahraga, genetik, usia, adanya stem sel, asal sel dan jenis sel (Zhang et al., 2009).

Efek hipoglikemik buah mahkota dewa juga berhubungan dengan kandungan $\mathrm{K}, \mathrm{Zn}$, $\mathrm{Ca}$, and $\mathrm{Cr}$ yang merupakan bahan hipoglikemik. Kandungan mineral tersebut tergantung dari jenis tanah tempat tanaman mahkota dewa tumbuh sehingga efek hipoglikemi tanaman mahkota dewa juga tergantung dari tempat dan asal penanaman. Media tumbuh mahkota dewa berpengaruh terhadap efek farmakologisnya dan media tanah dicampur dengan bahan organik (kompos, serbuk gergaji dans sekam padi) merupakan yang paling baik. Pemupukan dengan pupuk anorganik dapat merubah efek farmakologinya apalagi unsur kimia yang berbahaya dapat muncul pada buah yang umum dipakai sebagai bahan obat (Anggraeni, 2014).

Menurut Trucco (2008), dua jam setelah perlakuan yang merusak sel pulau Langerhans, sel pulau Langerhans terfragmentasi dan 2 hari kemudian tak dapat terdeteksi. Sel pulau Langerhans tampak kembali di sekitar jaringan yang rusak pada hari ketiga dengan dinding yang tipis dengan 1-2 dendrit. Saat dendrit bertambah jumlah dan panjang sel akan menjadi sama dengan sel pulau Langerhans secara morfologis dan fenotipnya. Kenaikan rerata populasinya antara 5-7 hari dan mencapai puncak pada hari ke 11. Selain itu sel duktus pankreatikus dapat mengalami transdiferensiasi menjadi sel $\beta$ yang merupakan proses fisiologis yang diakibatkan karena peningkatan metabolisme dan kerusakan jaringan sehingga proses regenerasi sel pulau Langerhans masih dapat bersifat fisiologis, seperti halnya terjadi pada orang obesitas, hamil dan pada pemberian deksametason.

Tingkat keamanan ekstrak air dan ekstrak etanol buah mahkota dewa melalui uji toksisitas akut dan subakut pada mencit sudah diteliti oleh Sulistiyani dkk. (2014). Rebusan dan ekstrak etanol dari buah mahkota dewa yang diberikan pada dosis tunggal $2500 \mathrm{mg} / \mathrm{kg}$ $\mathrm{BB}, 12500 \mathrm{mg} / \mathrm{kg} \mathrm{BB}$, dan $25000 \mathrm{mg} / \mathrm{kg} \mathrm{BB}$ tidak menimbulkan kematian hewan, sehingga LD50 tidak dapat ditetapkan secara pasti tetapi dapat diperkirakan bahwa LD50 ekstrak mahkota dewa jauh di atas $15000 \mathrm{mg} / \mathrm{kg} \mathrm{BB}$, sehingga dapat disimpulkan bahwa ekstrak tergolong nontoksik. Pada pada pemakain berulang selama 28 hari, rebusan maupun ekstrak etanol buah mahkota dewa sebanyak $50 \mathrm{mg} / \mathrm{kg} \mathrm{BB}, 100 \mathrm{mg} / \mathrm{kg} \mathrm{BB}$, dan $200 \mathrm{mg} / \mathrm{kg}$ $\mathrm{BB}$ juga tidak menimbulkan kematian hewan coba. Hasil pemeriksaan histopatologi menunjukkan terjadinya perubahan ringan yang irreversibel dan dan bukan merupakan akibat dari ekstrak yang diberikan. Gambaran histopatologi pada pemakaian berulang selama 28 hari (uji toksisitas subakut) menunjukkan ada mekanisme pertahanan tubuh yang ditimbulkan dari senyawa yang dicobakan.

Efek hipoglikemi yang dimulai pada pemberian ekstrak buah mahkota dewa $3 \mathrm{gr} /$ hari/200gBB menunjukkan bahwa ekstrak daging buah mahkota dewa dapat dijadikan obat alternatif diabetes melitus berdasarkan penelitian ilmiah bukan berdasar data empiris semata.

\section{KESIMPULAN}

1. Ekstrak buah mahkotadewa dapat menurunkan kadar glukosa darah pada tikus diabetes.

2. Ekstrak buah mahkotadewa dapat meregenerasi sel pulau Langerhans pankreas tikus diabetes.

3. Ekstrak buah mahkotadewa mulai konsentrasi 3gr/200gr/hari mampu meregenerasi sel pulau Langerhans pankreas tikus diabetes.

\section{UCAPAN TERIMAKASIH}

Penulis mengucapkan terimakasih kepada Dirjen Dikti Kemenristekdikti dan LPPM 
Unsoed yang menyediakan dana melalui Hibah Penelitian BLU, dan Lab Histologi Jurusan Kedokteran FK Unsoed sebagai tempat penelitian.

\section{DAFTAR PUSTAKA}

Abdel-Aziz MT, El-Asmar MF, Rezq AM. 2013.The effect of a novel curcumin derivative on pancreatic islet regeneration in experimental type-1 diabetes in rats (long term study). Diabet \& Metab Syndr. vol 5: 75 .

Anggraeni DN. 2014.Pengaruh Pemberian Variasi Dosis Pupuk Kandang Terhadap Pertumbuhan Tanaman Mahkota Dewa (Phaleria macrocarpa (Scheff.) Boerl.). Biogenesis. vol 2(1):16-20.

Arjadi F dan Susatyo P. 2017. Regenerasi Sel Pulau Langerhans Pada Tikus putih (Rattus norvegicus) Diabetes yang diberi Rebusan Daging Buah Mahkotadewa (Phaleria Macrocarpa (scheff.)Boerl). Prosiding Kedokteran Herba Annual Scintific Meeting. Yogyakarta: FK UGM.

Cicero L, Yenshou L, Arlene PB, Chen YC, Chiu SC, Yang WC. 2013. Herbal Therapies for Type 2 Diabetes Mellitus: Chemistry, Biology, and Potential Application of Selected Plants and Compounds. Evidence-Based Comp and Alt Med. vol 2013(2013): 33-36.

Daud R dan Afrida. 2014. Hubungan antara Pengetahuan Pasien DM dengan kepatuhan dalam menjalani Diet Khusus di RS Stella Maris Makasaar. Jurnal ilmiah Kesehatan Diagnosis. vol 5 (4): 403-408.

Darmono. 2009. Diagnosis dan Klasifikasi Diabetes Melitus dalam Buku Ajar Penyakit Dalam. Jilid I. Edisi V. M. Sjaifoellah N, Editor. Jakarta: Balai Penerbit Fakultas Kedokteran Universitas Indonesia. p. 590-94.

Djazuli M. 2011. Pengaruh Pupuk $P$ dan Mikoriza terhadap Produksi dan Mutu Simplisia Purwoceng. Buletin Littro. vol 22(2): 147-156.

Gotama IBI, Sugiarto S, Nurhadi M, Widiyastuti Y, Wahyono S, Prapti IJ. 2014
Inventaris Tanaman Obat Indonesia. Jilid VII. Jakarta, Departemen Kes. Badan Penelitian dan Pengembangan Kesehatan. hal 147-148.

Pribadi WA. 2012. Efektifitas Ekstrak Etanol Purwoceng (Pimpinella alpina) Terhadap Pertumbuhan Bobot Badan Tikus Betina Bunting pada Umur Kebuntingan 0-13 hari. [Skripsi]. Bogor: Fakultas Kedokteran Hewan. Institut Pertanian Bogor. hal 44.

Primasari A. 2017. Pemberian Infusa Daging Buah Mahkota Dewa (Phaleria macrocarpa (Scheff.) Boerl) Terhadap Kadar Glukosa Darah Mencit: Eksperimental Laboratoris. [Thesis]. Surabaya: Airlangga University.

Ramachandran B, Rajasekaran S. 2014. Blood glucose-lowering effect of Tectona grandis flowers in type 2 diabetic rats: A study on identification of active constituents and mechanisms for antidiabetic action. $J$ of Diab. vol 6(5): 427-437.

Sulistiyani, Evriza H, Zuhud EAM. 2004. Uji Toksisitas dan Mekanisme Hepatoproteksi Ekstrak Buah Mahkota Dewa (Phaleria macrocarpa (Scheff.) Boerl.) [Laporan Penelitian]. Pusat Studi BiofarmakaLPPM.

Sulistyoningrum E, Kautsari S, Susatyo P. 2010. Tinjauan Histologis Pembuluh Darah Tikus Putih (Rattus norvegicus) Diabetes yang diberi rebusan Daging Buah Mahkota Dewa. J. Mandala of Health. vol 4(2): 92-95.

.Sulistyoningrum E, Setiawati S, Nindyastuti H, Putra AN. 2012. Mahkota Dewa Mesocarp Infusion Improved Testicular Damage and Sperm Count In Diabetic Rat. Sains Medika. vol 4(2):115-124.

Widowati W. 2008. Potensi Antioksidan sebagai Antidiabetes. JKM. vol 7(2): 1-11.

Widyastuti N, Widiyani T, Listyawati S. 2008. Efek Teratogenik Ekstrak Buah Mahkota Dewa (Phaleria macrocarpa (Scheff.) Boerl.) pada Tikus Putih (Rattus norvegicus L.) Galur Winstar. Jurnal Biotek. vol 3(2): 56-62. 